\title{
A Study of Teachers' Perceptions of Involvement in Decision Making within Secondary Schools in Cameroon
}

\author{
Njouny Emmanuel Monjong \\ Master's Degree in Educational Administration, Doctoral Student, faculty of Education, Assistant Lecturer \\ Faculty of Education, University of Buea; njounyemma@yahoo.co.uk \\ Dr. Titanji Peter Fon \\ Vice Dean in charge of Programmes and Academic Affairs, Faculty of Education \\ University of Buea, Cameroon; titanj@yahoo.com
}

\section{Doi:10.5901/jesr.2016.v6n2p165}

\section{Abstract}

\begin{abstract}
The purpose of this study was to investigate the extent to which secondary grammar school principals share school leadership with teachers. Shared leadership was conceptualized as participatory decision making. Using a questionnaire developed from the related and conceptual literature, data were collected from 300 teachers and analysed using the Statistical Package for the Social Sciences (SPSS) version 22.0 for windows. The results of the data analysis were reported using descriptive statistics, more specifically frequencies, percentages, and means. Overall, of the nineteen items designed to capture teachers' perceptions of shared leadership in secondary grammar schools, only six (31.57\%) of them had means equal to or above the cut-off point of 3.00. In other words, for the most part principals do not adequately share leadership with teachers. Based on the findings, recommendations were made to guide policy and practice.
\end{abstract}

Keywords: Cameroon, secondary grammar school, teachers, principals, decision making, shared leadership.

\section{Introduction}

A key challenge facing all types of organizations is to raise the morale and commitment of employees and a common strategy calls for the adoption of shared decision making practices. Shared decision making is not seen as an end in itself. Rather, it is seen as having many positive organizational benefits, including but not limited to higher levels of motivation and commitment among employees, increased job satisfaction and higher performance and productivity. In the case of educational organizations, one of the recurring strategies calls for administrators to share leadership with others (e.g., Sergiovanni, 2001; Sergiovanni and Moore, 1989; Schein, 1985; Fullan, 1992, 2001; Harris, 2003; Barth, 1988).

There are other reasons, besides employee job satisfaction and school effectiveness, which can be used as arguments for shared decision making practices within educational organizations. For example, secondary schools, the focus of this study, are increasing operating within rapidly changing environments. The environments are becoming more complex, competitive and prone to frequent changes (Lewis, Welsh, Dehler \& Green, 2002). Stakeholder expectations are not only increasing but sometimes conflicting as well. Furthermore, schools are also complex organizations from the perspective of physical size, number of students, teachers and workers. A principal cannot therefore be everywhere at the same time to ensure that things are working the way they should. In addition, the legal foundation of schools (for example, presidential decrees, ministerial circular letters, international education initiatives, which Cameroon is signatory to) are rapidly changing. For example, decentralization is increasingly becoming a policy option with implications for those who inhabit schools.

The implications of the rapidly changing environments of secondary schools are many. For example, more pressure will be put on principals to find creative ways of facing related challenges. Sergiovanni (2001) has described educational administration as a humbling experience not only because the work of principals is done 'with and through others' but also because they work in environments characterized by limited resources. How to use these scarce resources should not be the responsibility of principals alone. Rather, the greatest challenge for principals should be that of creating and nurturing school cultures that are open to diversity of opinions and ways of doing things. Against this 
backdrop, the need to believe in the competence of teachers and other personnel to create environments characterized by shared decision making practices assumes greater urgency. Consequently, the overarching aim of this study is to investigate teachers' perceptions of the extent to which secondary school principals are sharing leadership with other actors.

\section{Statement of the Problem}

There is abundant literature which has brought out the positive individual and organizational consequences of shared decision making practices in organizations in general and educational organizations in particular. However, little is known if secondary school principals in the Republic of Cameroon are perceived by their collaborators as sharing critical decisions with them. The problems that have led to this study can be stated in question form as follows: Do principals involve teachers in decision making? Do they encourage teacher collaboration? Do they, as is expected by formal regulations, enable other appointed officials to do what is expected of them? The answers to these questions have not received a lot of research interest in spite of increasing calls for improved governance practices in secondary schools within African in general and Cameroon in particular. The answers to these questions constitute the focus of this study as they could be used to inform efforts aimed at improving the secondary education sub-sector which is witnessing explosions in demand as a consequence of demographic shifts in the population and international initiatives such as the Education for All initiative and the government's policy of free primary education.

There is reason to suspect that principals in this country may not be adequately sharing leadership with teachers in spite of abundant research that has brought out the advantages of shared leadership practices. The main reason stems from the process of becoming a principal in the Republic of Cameroon. For the most part, principals of secondary schools are not formally prepared through coursework related to the various work-related responsibilities. They are teachers, who through appointment, are abruptly thrust into administrative positions without consideration of whether or not they possess basic administrative competencies in the domains of knowledge, skills and professional attitudes. Those with the authority to appoint seem to base their actions on the logic that once an individual has been a teacher, he/she can automatically become an effective principal. This study would have achieved its goal if it provides data related to the extent to which leadership in secondary schools is shared and hopefully cause collective reflection and actions aimed at strengthening prevailing leadership within the secondary education sub-sector in Cameroon.

\section{Review of Literature}

For the purpose of this study, we will review literature on shared decision making and more particularly its benefits and the reasons why principals may be reluctant to get others involved in the process. There is a correlation between the prevailing leadership in schools and employee morale, commitment and productivity. Furthermore, a key principle on which Cameroon's policy on good governance (2004) is based is participation or getting others, based on their abilities, to be involved in making decisions that affect their lives as well as their respective institutions. In addition, a study on shared leadership has the potential to form the basis for individual and collective reflections about interpersonal relationships within secondary schools as well as shed light on their prevailing cultures (Fullan, 1992, 2001; Schein, 1985). Schein (1985), cited in Fullan, (1992) asserts that the only thing of real importance that needs to be done by principals is to create and manage a healthy culture. One of the ways of doing this is to encourage norms of participation in decision making (Barth, 1988; Sergiovanni \& Moore, 1989; Neidt, 1987).

In the Republic of Cameroon, the functions of principals are clearly stated in The Handbook for Heads (1996) as administrative, pedagogic, social, and financial management. Alone, principals cannot effectively perform these functions. The involvement of teachers should not be restricted to the implementation of hierarchically determined purposes or decisions because gone are the days when leadership for schooling was myopically conceptualized as the sole responsibility of elected or appointed officials in central education offices or at the institutional level. For schools to increase their potential to achieve the desired outcomes that give legitimacy to their existence, principals must learn to share some of their responsibilities and the decisions that impact schools (Sergiovanni, 2000; Blasé \& Blasé, 1998).

Shared leadership is being increasingly acknowledged as one of the best approaches to organize and run formal organizations in general and educational organizations in particular. However, much research has not been conducted in this country on the quality of prevailing leadership in schools. The need for principals to share leadership is probably more urgent in Cameroon than in other contexts because majority of principals do not possess basic administrative competence. The absence of basic competence in the domains of knowledge, skills and appropriate attitudes, should 
logically increase their dependence on others for ideas towards efforts to create productive teaching and learning environments. We believe that research is urgently needed on the prevailing leadership behaviours of principals considering the role schools are expected to play towards ensuring that quality education is available to all regardless of gender, socio-economic background and those with various forms of disabilities, among others. Furthermore, quality secondary education is widely acknowledged as a fundamental strategy for achieving the millennium development goals.

Concerns are increasingly being raised about the ability of secondary schools to provide quality secondary education to all students (for example, The African Union in its Second Draft Plan of Action 2006-2015; The Report of the National Education Forum of 1995). These concerns, among others include, the relevance of taught content, inequalities of opportunities based on variables such as gender, socio-economic background and various forms of disabilities, shortage of vital human and material inputs, and institutional management capacity. Good governance is increasingly being identified as one of the strategies that must constitute part of a more comprehensive reform strategy. Cameroon's good governance policy is, amongst other things, based on principles of shared leadership.

\section{The Concept of Shared Decision Making}

Sharing decision making with others is not a new concept. In the old testament of the bible, Moses is advised by his father-in-law, Jethro, to share responsibilities with others as contained in the quotation below:

\section{'...thou shall have rulers of thousands, and rulers of hundreds, rulers of fifties, and rulers of ten...and it shall be, that every great matter they shall bring to you, but every small matter they shall judge; so shall it be easier for yourself, and they shall bear the burden with you' (Exodus 18: 21-22).}

The goal of sharing leadership with others, regardless of the form it takes, is to ensure that every stakeholder contributes to the success of a school based on his/her ability (Camburn et al., 2003; Day et al., 2003; Duigan, 1990; Elmore, 1999). Leadership is participatory or shared when important decisions that shape the lives of employees and the organization are jointly made by the leader, subordinates and other stakeholders (Somech \& Wenderow, 2006; Katzenmeyer et al., 2001). From an organizational perspective, there is a positive relationship between shared decision making and employee morale, performance and productivity (Schermerhorn, 1984). For example, employees involved in the process of making decisions that affect their work lives are more likely to feel a stronger sense of ownership of the decision(s) and consequently more likely to increase their commitment to the implementation process (Fullan, 1992, 2001). In addition, there is also increased probability that decisions made will be of better quality than those made by a principal alone (Dent, 2003; Leithwood et al., 2003, 2000, 1999; Katzenmeyer et al., 2001).

However, researchers (Benson \& Malone, 1987; Somech \& Wenderow, 2006) have also suggested that teachers and other personnel do not desire involvement in all domains of decision making. Many scholars are of the opinion that teachers only prefer involvement in making decisions that have direct teaching and learning implications and allow routine day-to-day administrative decisions to be made by principals and other administrators (for example, see Benson \& Malone, 1987; Fiedler, 1989, 1995). This preference by teachers enables them to devote more time to teaching and ensuring that students are learning. The implication here is that there are areas of decision making in which teachers desire involvement and there are others they do not. From a contingency perspective the decision of a principal to share or not share decision making with teachers and other stakeholders will depend on the characteristics of the leader, subordinates, superiors, the situation and ability of the leader to adapt his/her style to situational variables (Fiedler, 1989, 1995; Hersey \& Blanchard, 1982; Miller \& Monge, 1986; Vroom, 1964; Vroom \& Jago, 1998; Glickman, 1985). Glickman (1985) suggests that teachers are likely to be interested in making decisions in areas in which they have competence, care about, and decisions with the potential to make a difference in teaching and learning.

Findings from previous research cited by Somech \& Wenderow (2006) (e.g., Miller \& Monge, 1986; Vroom \& Jago, 1998; Fiedler, 1989, 1995), argue that the effects of a particular leadership style cannot be investigated without due consideration of situational variables within the work context within which the style was used. The implication here is that the effectiveness of a principal will also depend on situational variables with the potential to substitute, neutralize, or enhance the effects of a leader's behaviour (Somech \& Wenderow, 2006).

The relationship between shared leadership in the form of participation in decision making and individual and organizational benefits is well documented in the literature. The relationship is characterized by intervening variables such as the decision domain, technical and managerial (Duke \& Gansneder, 1990; Benson \& Malone, 1987; Herriot \& Firestone, 1984), the maturity level of subordinates in terms of their experience as well as possession of relevant knowledge, skills and attitudes (Fiedler, 1989, 1995; Glickman, 1985) as well as accountability concerns (Glickman, 
1985). The choice of a leadership style, from a contingency theoretical perspective depends on situational variables (Vroom \& Jago, 1998; Mumford, 1986) because no single style will lead to effectiveness in all situations. Technical decisions have to do with issues of teaching and learning (e.g., instructional and student discipline policies), while decisions which have to do with routine operations of a school (allocating resources, hiring staff, conducting performance appraisals, amongst others) fall within the management domain (Duke \& Gansneder, 1990; Herriot \& Firestone, 1984). The suggestion here is that teachers will prefer involvement in decisions that have to do with teaching and learning rather than with routine administrative issues of a school.

According to the cognitive resource theory of leadership (Fiedler, 1989, 1995; Glickman, 1985), employee competence is a critical determinant of shared leadership or participatory decision making approaches. They argue that subordinates who possess the competence required for decision making are more likely to prefer a less directive leadership style (Sagie, 1996, 1997; Somech \& Wenderow, 2006). On the other hand when the leader is more competent, a more directive style is preferred. Within the context of secondary schools in Cameroon, principals are likely to possess greater administrative competence (as a result of practical experience) while technical competence relevant to teaching and learning is more likely to be possessed by teachers or shared by both teachers and administrators. This suggest that principals should be less participatory in making routine or technical decisions and participate more when instructional matters are concerned. However, we are not providing a rule of thumb because besides the possession of competence, there are other considerations when choosing a leadership style.

Advocates of participatory decision making argue that employees who have input into decisions that affect their lives are likely to experienced greater job satisfaction than those who are not involved (Alderfer, 1972; McClelland, 1961; Duignan, 1990; Elmore, 1999; Harris, 2003; Katzenmeyer et al., 2001; Leithwood et al., 2003). Working, for the most part, behind closed classroom doors, teachers make many instruction-related decisions (Saphier \& Gower, 1987; Benson \& Malone, 1987; Conley, 1991). However, there is empirical evidence that, for the most part, the same is not true when it comes to broad decisions that affect the school as an organization. For example, Sarason (1982) has asserted that teachers are treated no differently than they have been accused of treating students, mainly as recipients rather than involved stakeholders in the process of making critical decisions.

The relationship between involvement in decision making and employee morale, performance, and productivity is therefore very complex. It will be affected by variables such as the prior experiences and individual characteristics of teachers (Sarason, 1982; Goodlad, 1982, 1984; Benson \& Malone, 1987), and the decision domain (Vroom, 1964; Vroom \& Jago, 1998; Neidt, 1987; Benson \& Malone, 1987; Somech \& Wenderow, 2006; Duke \& Gansneder, 1990; Herriot \& Firestone, 1984; Fiedler, 1989, 1995). Sarason (1982) and Goodlad (1984) have suggested that some teachers may be apprehensive or reluctant about more decision making power because they have become too used to cultures wherein major decisions are made at the top of the school hierarchy. They further explain that some teachers may not desire greater involvement because it takes away time from the activity that gives them the greatest satisfaction, teaching and making a difference in the lives of children.

Research by Neidt (1987), Benson \& Malone (1987), Patterson, 1986, and Conley (1991) has enriched understanding of the concept of decision making within the context of educational organizations. Neidt (1987) studied factors related to secondary school teachers' satisfaction with shared decision-making. The dependent variables in the study were general satisfaction with shared decision-making and specific satisfaction with a particular decision-making experience. Independent variables were knowledge of the topic, degree of perceived influence and involvement, phase entered in the decision-making process, benefits of the decision, expected and unexpected rewards, extent of implementation and attitude towards teaching. Teachers in the study reported deriving most of their satisfaction from shared decision-making experiences that benefited them as individuals and the school as an institution. They also reported greater satisfaction when they felt influential and when the decisions were successfully implemented.

In the Benson and Malone study (1987), twelve different areas of decision-making were broken down into technical and managerial decision domains. Using a 4 point Likert-type scale, respondents indicated how much influence they had in each decision and how much influence they wished to have. Job satisfaction in the study was conceptualised as a function of feelings of decision deprivation, saturation and equilibrium. Data analysis revealed that subjects felt more deprived in managerial decision-making areas than in the technical areas that dealt with teaching and learning. The researchers concluded that teachers would love to be more involved in a broader array of decisions as long as they felt their involvement was meaningful and did not reduce instructional time.

The above researchers have shed light on an important issue in research on participation in decision-making, its conceptualisation. In her review of relevant research, Conley (1991) makes a distinction between relative and absolute participation. Absolute participation suggests that all teachers want and value involvement in all decision areas or 
domains, while relative participation suggests that some decision areas will be of more interest to teachers than others. According to Conley, research prior to the 1970s conceptualised and operationalized participation in decision-making in absolute rather than relative terms. In her review, participation is viewed from three perspectives: teachers' expectations, forms of participation and influence in decision making. She concluded that teachers do not equally value participation in all decision domains. To Cogliser et al., (2000), and Meyer and Rowan (1978), teachers do not desire participation in broad and routine decisions. They are willing to relinquish the opportunity to affect broad and routine management decisions for classroom autonomy. In this way, he continues, the interests of teachers, school administrators, and policy makers are served and interpersonal conflicts avoided.

\subsection{Why Share Decision-making?}

Researchers (e.g., Fullan, 2001; Benson \& Malone, 1987; Schermerhorn, 1984; Katzenmeyer et al., 2001; Leithwood et al., 2003) have concluded that shared decision making has individual and organizational benefits. From an individual perspective, it is a good time management strategy for a principal. The argument here is that time is a very scarce resource, considering the expectations of the principalship. When principals share decision making with others, they free up time that could be devoted to more important and strategic issues which others cannot handle. It is also a strategy to motivate employees, to send a message to subordinates involved that their competence and character are trusted (Alderfer, 1972; McClelland, 1961). When subordinates receive regular invitations to be involved in making decisions that affect their lives, they are likely to be more motivated to increase their commitment to the organization. Sharing decision making with subordinates is also a strategy to socialize them for future roles as school administrators.

In addition, secondary school principals today are very busy people because the environments within which they work and the expectations on schools are increasingly becoming very complex (Lewis, Welsh, Dehler \& Green, 2002). Advances in technology, challenges of globalisation, increasingly diverse and sometimes conflicting stakeholder expectations (parents, students, the government, employers, and alumni, among others) are adding to the pressure on principals. Furthermore, the changing legislative framework, regional and other international education initiatives (for example, Law No. 98/004 of April 14, 1998 to lay down guidelines for basic and secondary education in Cameroon; The African Union's Second Decade of Education for Africa (2006-2015): Draft Plan for Action (2006), increasing calls for Education for All by 2015, and the need to achieve the Eight Millennium Development Goals (UNESCO, 2005) agreed upon in Jomtien, Thailand by 147 countries, Cameroon included, exert enormous pressures on school principals. Against this backdrop, the effectiveness of a school requires the efforts of more than one person, regardless of his/her propensity to hard work. Getting other stakeholders involved is a survival strategy that requires a paradigm shift in terms of the conception and practice of school administration.

The legal framework which provides the foundation of administrative behaviour recognizes the need for shared leadership in secondary schools (e.g., Republic of Cameroon, 1998, 2004). One of the principles underlying Cameroon's policy on good governance is belief in participatory decision making and the creation of enabling environments in which all stakeholders share their ideas, opinions on critical areas of the organization in order to have a shared vision. The nation's good governance policy is characterized by principles of participation, transparency and accountability. The country has to respect internal commitments, fulfil its regional and other international education engagements. These are likely to be achieved more effectively and efficiently when principals and other school administrators share leadership.

These initiatives place enormous burden on all education personnel, particularly principals. Faced with enormous challenges, principals must, in their own interest and that of secondary schools, work closely with staff and other stakeholders to enable the secondary school sub-sector achieve its purpose and objectives which are contained in Law No. 98/004 of 14 April, 1998. In its general provisions the Law states that 'Education shall be a top priority of the nation' (Section 3 (1). The state promises in Section 6, to 'guarantee the right of every child to education' while in Section 7, calls for 'equal opportunities for education to all, without discrimination as to gender, political, philosophical or religious opinion, social, cultural, linguistic or geographical origin'. Against this backdrop, there is need for a new conception and practice of leadership. Principals need to conceptualise leadership as a shared responsibility and the need to do so is widely acknowledged in the literature (Sergiovanni, 2000; Lewis, Welsh, Dehler, \& Green, 2002).

Paying attention to how decisions are made within secondary schools is therefore important because of the vital contributions they are expected to make towards the sustainable development of the country. Shared leadership is associated with enhanced employee morale, commitment and productivity (Sergiovanni, 1987, 2000; Schermerhorn, 1984; Hoy \& Miskel, 2000; Fullan, 1992, 2001) quality of decisions made and commitment to their implementation (Fullan, 1992, 2001) and enhanced cognitive capacities of those involved by expanding their repertoire of knowledge, 
skills and attitudes (Cannon-Bowers, Tannebaum, Salas \& Volpe, 1995; Durham, Knight \& Locke, 1997; Latham, Winters \& Locke, 1994, Sagie, 1996, 1997). According to these researchers, besides motivational benefits, participatory leadership offers a learning opportunity to everybody involved in the experience. Furthermore, a study on decision making processes within secondary schools has the potential to form the basis for individual and collective reflection about interpersonal relationships as well as shed light on their prevailing cultures (Sergiovanni, 1987, 2000; Fullan, 1992, 2001; Barth, 1988).

Though shared decision making may have negative consequences such as reduced instructional time and potential for interpersonal conflicts, it has more benefits for teachers as individuals and the secondary schools in which they work. Benefits include a greater sense of workplace democracy and greater probability that adopted decisions of higher quality will be made and implemented. Organizational theorists (Weick, 1983; Patterson, 1986) have used concepts such as 'loose coupling' and schools as 'non-rational systems' to argue that schools are not rational bureaucracies in which decisions made at the top echelons of the organizational hierarchy are logically accepted and implemented by teachers. This point of view which has been supported by Fullan (1982; 2001), who has written extensively on the process of educational change, is based on the assumption that because teachers work in relative isolation, they stand between policy making and implementation.

Shared decision making fosters a belief in democratic principles and processes such as self determination and participation. Working within an increasingly complex environment, principals need to share leadership with other stakeholders. Conceptualising leadership as a shared experience is a vital strategy to build and nurture positive school cultures characterized by collegiality, higher employee morale, commitment and productivity, and respect for diversity (Fullan, 1992; Schein, 1985).

\subsection{Why Principals may be Reluctant to Share Decision Making}

If shared leadership is advantageous to principals, teachers, students, other stakeholders and schools as organizations, a logical question to ask and answer is why some principals may be reluctant to share leadership with others. Researchers have shed light on this question using the cognitive resource theory of leadership (Fiedler, 1989, 1995; Glickman, 1985). According to the theory, employee competence is a critical determinant of shared leadership within organizations. The implication is that if principals do not have confidence that teachers and other collaborators have the relevant capacity in the domains of knowledge, skills and attitudes, they are unlikely to share leadership with them. Since most principals in Cameroon are not trained school administrators, the cognitive theory can also be used to explain their inability or reluctance to share leadership. In other words, if they do not share leadership, it is because they do not have the knowledge, skills and attitudes to do so.

Glickman (1985), Fiedler (1989), Hersey \& Blanchard (1982) have provided guidelines to help school administrators know when to share and not share leadership. According to them, when relevant expertise and commitment are shared by principals and teachers, a more participatory decision making approach should be adopted. On the other hand the principal should be directive when subordinates do not possess the needed capacity and the principal possesses it. Furthermore, if subordinates have the relevant expertise and commitment and the principal does not, he/she should allow subordinates to make the decision.

\section{Methodology}

The survey research design was adopted for this study. Data were collected using a Likert- type questionnaire with 19 items and four response options anchored as follows: strongly disagree $=1$, disagree $=2$, agree $=3$, and strongly agree $=4$. The questionnaire items were derived from the review of related literature and the functions of principals. Attached to each questionnaire was a cover letter which explained the purpose of the study, emphasized the importance of honest responses, and guaranteed the confidentiality of the subjects. In addition to questionnaire items related to the research objectives, subjects were required to provide demographic information related to gender, their highest academic qualification, length of teaching experience, and type of school in which they work (public, denominational or lay private). Postgraduate students, some of whom are secondary school teachers, were used for pilot testing of the questionnaire. Terms of reference were clarity of instructions, response options and item content, and relevance to the research objectives. Data were collected from 300 teachers, invited to mark the Cameroon General Certificate of Education Examination at the Ordinary Level, with the assistance of chief examiners in each of the subject areas. This, we think, partly contributed to the $100 \%$ response rate. 
The cluster sampling technique was used to select a sample of 300 teachers from a population of 1825. Cluster sampling was used because during the G.C.E marking exercise, teachers of the same subject discipline are usually assigned to different classrooms. In this light, they were viewed as existing in clusters. The following criteria were used to randomly select the required number of teachers. For academic disciplines having less than one hundred markers, 10 teachers were selected, 20 from subjects with more than 100 and less than 200 teachers; for those with between 200 and 300 teachers, 30 were selected; 50 teachers were selected from clusters with more than 300 markers.

\section{Findings}

Collected data were analysed using the statistical package for the social sciences (SPSS) version 22.0 to obtain descriptive statistics: frequencies, percentages and means.

\section{Demographic Characteristics}

The demographic characteristics of the sample were as follows: public school teachers (158 (52.67\%), while 120 (40\%) were denominational or mission secondary school teachers. 22 teachers $(7.33 \%)$ did not mention their school type; gender: males 199 (66.33\%), females 98 (32.67\%); Length of teaching experience in years: 0-5, 54 (18\%), 6-10, 104 (34.67\%), 11-15, 71 (23.67\%), 16-20, 52 (17.33\%), above 20 years, 19 (6.33\%); highest academic qualification in descending frequencies: 128 (42\%) were holders of Bachelor's degrees, 90 (30\%) were holders of DIPES I, 60 (20\%), DIPES II, 11 (3\%) had post-graduate diplomas while 8 (2\%) held masters' degrees.

\section{Analysis of Data Related to the Research Focus}

Nineteen items on the questionnaire were designed to capture the perceptions of teachers of their involvement in decision making in secondary schools. Table 1 presents the means of the 19 questionnaire items. To interpret the findings, a cut-off point is set at a mean of 3.00 . Means below 3.00 indicate that principals are not adequately sharing leadership with others in the area represented by the statement.

Table 1: Means of responses to questionnaire items presented in descending order

\begin{tabular}{|c|l|c|}
\hline S/N. & Statement: My principal: & Mean \\
\hline 1. & Often holds meetings during which teachers are encouraged to honestly express their opinions & 3.38 \\
\hline 2. & When you talk to him/her, he/she pays attention to what your are saying & 3.20 \\
\hline 3. & Has the habit of getting staff together to discuss school-related issues & 3.18 \\
\hline 4. & Encourages a lot of team work & 3.14 \\
\hline 5. & Is friendly and approachable & 3.12 \\
\hline 6. & Is always ready and willing to listen to complaints of teachers & 3.01 \\
\hline 7. & Discusses work-related problems with teachers & 2.87 \\
\hline 8. & Knows how teachers think and feel about things in the school & 2.85 \\
\hline 9. & Encourages teachers to participate in making important decisions & 2.81 \\
\hline 10. & Allows teachers to choose textbooks to use from the list suggested by the ministry of education & 2.74 \\
\hline 11. & Takes my suggestions seriously & 2.70 \\
\hline 12. & Encourages teachers to speak up when they disagree with him/her & 2.63 \\
\hline 13. & Encourages teachers to determine instructional material to be purchased & 2.58 \\
\hline 14. & Makes most decisions without consulting teachers & 2.51 \\
\hline 15. & Regularly assigns teachers to check the state of instructional materials & 2.46 \\
\hline 16. & Refuses to give in when people disagree with him/her & 2.34 \\
\hline 17. & Allows teachers to have much influence in what goes on in my school & 2.22 \\
\hline 18. & Allows teachers to have much influence in decisions he/she makes that affect them & 2.21 \\
\hline 19. & Involves teachers in making decisions that have to do with admission of students & 2.00 \\
\hline
\end{tabular}

Of the nineteen items designed to capture teachers' perceptions of shared leadership in secondary grammar schools, only six (31.57\%) of them had means equal to or above the cut-off point of 3.00. In other words, for the most part principals do not adequately share leadership with teachers. Means of items close to 4 (for positively worded items) or 1 
(for negatively worded items) indicate high levels of shared leadership practices. The study reveals that principals share decision making in some areas and not others. The means range from $2.00-3.38$ with $68.42 \%$ of the items of the questionnaire having means below the cut-off point of 3.00. In other words, principals are not very effective in getting others involved in decisions that affect secondary grammar school.

\section{Discussion}

Considering the positive individuals and organizational consequences of participatory decision making such as fostering a belief in democratic principles and processes, improved employee morale, commitment and productivity (Hoy \& Miskel, 2000; Schermerhorn, 1984; Sergiovanni, 1987, 2000) enhanced quality of decisions made and their subsequent implementation (Fullan, 1992, 2001), enhanced cognitive capacities of those involved in the decision making process (Cannon-Bowers, Tannebaum, Salas, \& Volpe, 1995; Durham, Knight, \& Locke, 1997; Latham, Winters \& Locke, 1994; Sagie, 1996, 1997) and enhanced capacity of secondary schools to achieve the objectives of secondary education as laid out in Law No. 98/004 of April 14, 1998 as well as other regional and international education initiatives such as the attainment of the millennium development goals, these findings do not augur well for secondary education in Cameroon.

In its Second Decade of Education for Africa (2006-2015): Draft Plan of Action the African Union (2006) identifies quality institutional management as one of its key strategic objectives. It was adopted by the Conference of education ministers of member states. According to the African Union, the quality of education, in the past, was considered as an estimate of quantitative provisions in the form of level of investment. Today, this has changed with greater emphasis being paid to processes and outcomes (African Union, 2006). At the level of Cameroon, there is also recognition of the need for appointed officials to get others involved in decisions that affect organizations, especially within the public sector (Republic of Cameroon, 2004).

Quality education is a fundamental human right acknowledged by the constitution of Cameroon, The AU's Second Decade of Education for Africa (2006-2015), Draft Plan of Action (June 2006), UNESCO (2005) and UNICEF, (2003). It is considered by UNESCO as an investment in people as it contributes to the achievement of the Millenium Development Goals (MDGs), and constitutes an effective strategy to fight poverty and build well functioning democracies. Improving the quality of education is therefore widely recognized as a strategic objective for all countries and probably more so for developing countries like Cameroon.

There are many ways of enhancing access and improving the quality of education. One of the core ones is to monitor what is happening in schools, the quality of prevailing leadership practices as this has the potential to affect teacher's commitment to teaching and children's commitment to learning (Rutter et al., 1979; Edmonds, 1979; Brookover et al., 1979). If we do not pay attention to the quality of prevailing leadership behaviours of principals, it will almost be tantamount to arguing, like researchers in the 1960s (e.g., Coleman et al., 1966; Kozol, 1967) that within-school factors do not make a difference in students' experiences with schooling and subsequently, their academic achievement.

In terms of the demographic characteristics of the sample of teachers involved in this study (academic qualifications and length of teaching experience) the teachers are of high quality to be able to be part of the decision making process in school. For example, 246 have had teaching experiences ranging from 6 to above 20 years. This implies that they have acquired a lot of experience related to issues of teaching and learning that should be tapped and used in efforts towards creating more effective and efficient secondary schools. Furthermore, there is a good gender mix which can be tapped and used as circumstances dictate. For example, if sensitive decisions have to be made about female students, secondary school principals can draw from the experiences of female teachers. Not getting teachers involved is contrary to findings from research on adult learning and development.

We observed lack of consistency in some of the responses. For example, principals are reported to hold meetings during which they encourage teachers to honestly share their opinions (means of 3.38) and the mean of 2.51 which reflects teachers' perception that most decisions are made without their input. These means are significantly different. This can be explained by the fact that the first item is more general in its orientation while the second deals with the individual. Although we feel that the findings of this study yield an insight into the leadership behaviours of principals, especially within the context of getting others involved in the decision making process, there were some weaknesses. Firstly, even though the number of teachers involved in the study was considerable, they came from many different schools and consequently do not reflect the particular leadership behaviours within specific schools. This may also partly explain inconsistencies in the findings. 


\section{Conclusions and Implications}

Research on effective schools (e.g., Brookover et al., 1979; Edmonds, 1979; Goodlad, 1982; Rutter et al., 1979), dispelled earlier pessimism by Coleman et al. (1966) and Kozol (1967), among others, that factors within schools made little or no difference in the experiences of children of various backgrounds in schools and their subsequent achievement of desired outcomes. Institutional management capacity, school culture or ethos, and norms of collegiality, were some of the factors identified to make a difference in school improvement efforts. Secondary school principals are responsible for creating and nurturing environments in which these effectiveness variables can be experienced by all stakeholders. How decisions are made is one of the ways of creating and sustaining norms of collegiality, a positive school culture and climate and enhancing student achievement.

The findings of this study have contributed to research on decision making within educational organizations in general and in Cameroon. In addition, the findings constitute an addition to knowledge and practice because they have profound implications for institutions responsible for the preparation of educational administrators, policy makers and principals themselves. Even though the study strongly recommends initiatives aimed at enhancing the capacity of principals in the triple domains of knowledge, skills and attitudes, principals themselves should also be concerned about their own continuing professional development. Furthermore, more research needs to be carried out in order to identify specific areas in which teachers desire involvement in decision making, as well as a similar study in other parts of the country as well as different levels of education (for example, basic and tertiary). Working within an increasingly complex environment, principals need to share leadership with other stakeholders. When they are not doing so at higher levels, as strongly suggested by this study, we need to worry and seek explanations and possible solutions. As Secretary General of the United Nations, in the preface to the millennium development goals, Koffi A. Annan stated 'we must do more than talk about our future...We must start to create it, now'. To create it within educational organizations requires, among other things, paying attention to the quality of prevailing leadership in schools.

\section{References}

African Union (2006). Second Decade of Education For Africa (2006-2015): Draft Plan of Action. Addis Ababa: Author.

Adelfer, C. P. (1972). Existence, relatedness and growth. New York: The Free Press.

Barth, R.S. (1988). Principals, teachers and school leadership. Phi Delta Kappan, 69, 639-642.

Benson, N. \& Malone, P. (1987). Teachers' beliefs about shared decision making and work alienation. Education, 107 (3), 244-251.

Blasé, J. \& Blasé J. (1998), Handbook of instructional leadership. Thousand Oaks, CA: Corwin Press.

Brookover, W.; Beady, C.; Flood, P.; Schweiter, J.; \& Wisenbaker, J. (1979). School social systems and students achievement. Schools can make a difference. New York: Praeger.

Camburn, E., Rowan, B., \& Taylor, J. E. (2003). Distributed leadership in schools: The case of elementary schools adopting comprehensive school reform models. Educational Evaluation and Policy Analysis, 25 (4), 347-373.

Cannon-Bowers, J. A., Tannenbaum, S. I., Salas, E., \& Volpe, C. E. (1995). Defining competencies and establishing team training requirements. In R. A. Guzzo, E. Salas, E. et al., (Eds.), Team effectiveness and decision making in organizations (pp. 333-380). San Francisco: Jossey-Bass.

Cogliser, C. C., \& Schriesheim, C. A. (2000). Exploring work unit context and leader-member exchange: A multi-level perspective. Journal of Organizational Behaviour, 21, 487-511.

Coleman, J. S.; Campbell, E. Q. ; Hobson, C. J. ; McPartland, J.; Mood, A. M.; Weinfield, F. D.; \& York, R. L. (1966). Equality of educational opportunity. Washington, D.C.: U.S. Government Printing Office.

Conley, S. (1991). Review of research on teacher participation in school decision making. In Gerald Grant (ed.) Review of research in education. Washington D.C.: AERA.

Day, C., \& Harris, A. (2003). Teacher leadership, reflective practice, and school improvement. In K. Leithwood \& P. Hallinger (Eds). International Handbook of Educational Leadership and administration (2nd. Ed.), pp. 724-749.

Dent, F. S. (2003). The leadership pocketbook. Alresford, Hants, U.K.: Management Pocketbooks Ltd.

Duignan, P. A. (1990). School-based decision-making and management: Retrospect and prospect. In J. D. Chapman (Ed.), Schoolbased decision-making and management (pp. 327-346). New York: Falmer Press.

Duke, D. L., \& Gansneder, B. (1990). Teacher empowerment: the view from the classroom. Educational Policy, 4, 145-160.

Durham, C. C., Knight, D., \& Locke, E. A. (1997). Effects of leader role, team-set goal difficulty, efficacy, and tactics on team effectiveness. Organizational Behavior and Human Decision Processes, 72, 203-231.

Edmonds, R. (1979). Effective schools for the urban poor. Educational Leadership 37 (1): 15-24.

Elmore, R. (1999). Building a new structure for school leadership. American Educator, Winter 1999-2000.

Fiedler, F. E. (1989). The effective utilization of intellectual abilities and job-relevant knowledge in group performance: Cognitive resource theory and an agenda for the future. Applied Psychology: An International Review, 38, 289-304.

Fiedler, F. E. (1995). Cognitive resources and leadership performance. Applied Psychology: An International Review, 44, 5-28. 
Fullan, M. G. (1992). Visions that blind. Educational Leadership, 49, (February 1992): 19-20.

Fullan, M. G. (2001). The new meaning of educational change (3rd. ed.). New York: Teachers College Press (change all Fullan references in other articles)

Glickman, C.D. (1985). Supervision of instruction: A developmental approach. Boston: Allyn \& Bacon.

Goodlad, G. I. (1982). A study of schooling. Paper presented to the Standford Teacher education Project, Standford, CA. January, 28.

Goodlad, J. (1984). A place called school. New York: McGraw-Hill.

Harris, A. (2003). Teacher leadership as distributed leadership: Heresy, fantasy or possibility? School Leadership and Management, 23 (3), 313-324.

Harris, A. (2003). Distributed leadership and school improvement. Educational Management, Administration \& Leadership, 32 (4), $11-24$. (Add both Harris references to paper)

Herriot, R. E., \& Firestone, W. A. (1984). Two images of schools as organizations: A refinement and elaboration. Educational Administration Quarterly, 20, 41-57.

Hersey, P., \& Blanchard, K. (1982). Management of organizational behaviour: Utilizing human resources (4th. Ed.). Englewood Cliffs, NJ: Prentice Hall.

Herzberg, F., Mausner, B., \& Snyderman, R. (1959). The motivation to work. New York: John Wiley.

Holy Bible, (2001). Exodus 18, 21-22. Minsk, Belarus: Printcorp.

Hoy, W. K. \& Miskel, C. G. (2000). Educational administration: Theory, research and practice (5th Ed.). New York: McGraw-Hill.

Katzenmeyer, M., \& Moller, G. (2001). Awakening the sleeping giant: Helping teachers develop as leaders (2nd. Ed.). Thousand Oaks, CA: Corwin Press.

Kozol, J. (1967). Death at an early age. Boston: Houghton-Mifflin.

Latham, G. P., Winters, D. C., \& Locke, E. A. (1994). Cognitive and motivational effects of participation: A mediator study. Journal of Organizational Behavior, 15, 49-64.

Leithwood, K., \& Jantzi, D. (1999). The relative effects of principal and teacher sources of leadership on student engagement with school. Educational Administration Quarterly, 35, 679-706.

Leithwood, K., \& Jantzi, D (2000). Principal and teacher leadership effects: A replication. School Leadership \& Management, 20 (4), 415-434.

Leithwood, K., Jantzi, D., \& Steinbach, R. (1999). Changing leadership for changing times. Buckingham: Open University Press.

Leithwood, K., Riehl, C. (2003). What do we already know about successful leadership? Chicago, IL: AERA Division A.

Lewis, M. W., Welsh, M. A., Dehler, G. E., \& Green, S. G. (2002). Product development tensions: Exploring contrasting styles of product management. The Academy of Management Journal, 45, 546-564.

Maslow, A. H. (1954). Motivation and personality. New York: Harper \& Row.

McClelland, D. C. (1961). The achieving society. New York: Van Nostrand.

Meyer, J. W., \& Rowan, B. (1978). The structure of educational organizations. In J. V. Baldridge \& T. Deal (Eds.), The dynamics of organizational change in education, (pp. 60-87). California: McCutchan.

Miller, K. I., \& Monge, P. R. (1986). Participation, satisfaction and productivity: A meta-analytic review. Academy of Management Journal, 29, 727-753.

MINEDUC. (1995). The national education forum. Yaounde: Author.

Mumford, D. M. (1986). Leadership in the organizational context: A conceptual approach and its applications. Journal of Applied Social Psychology, 16, 508-531

Neidt, W. (1987). Factors contributing to teachers' satisfaction with shared decision making. Dissertation Abstracts, 48, (10), 25004-A

Patterson, J. L. (1986). Productive school systems for a nonrational world. Alexandria: Association for Supervision and Curriculum Development.

Rebublic of Cameroon. (2004). Cameroon: The way forward for good governance. Yaounde: Imprimerie Saint-Paul.

Republic of Cameroon. (1998). Law no. 98/004 of April 14, 1998 to lay down guidelines for education in Cameroon. Yaounde: Author.

Rutter, M.; Maughan, B.; Mortimore, P.; Ouston, J.; \& Smith, A. (1979). Fiteen thousand hours: Secondary schools and their effects on children. Cambridge, Mass.: Harvard University Press.

Sarason, S.B. (1982). The culture of the school and the problem of change. Boston: Allyn \& Bacon.

Sagie, A. (1996). The effects of leader's communication style and participative goal setting on performance and attitudes. Human Performance, 9, 51-64.

Sagie, A. (1997). Leader direction and employee participation in decision making: Contradictory or compatible practices? Applied Psychology: An International Review, 46, 387-452.

Saphier, J., \& Gower, R. (1987). The skillful teacher: Building your teaching skills. Carlisle, MA.: Research for Better Teaching.

Schein, E. (1985). Organizational cultures and leadership: A dynamic view. San Francisco: Jossey-Bass.

Schermerhorn, J. R. Jr. (1984). Management for productivity. New York: John Wiley \& Sons.

Sergiovanni, T. J. (1987). The principalship: A reflective practice perspective. Boston: Allyn \& Bacon.

Sergiovanni, T. J., \& Moore, J. H. (1989). Schooling for tomorrow : Directing reforms to issues that count. Boston: Allyn \& Bacon.

Sergiovanni T. J. (2000). The life world of leadership. San Francisco: Jossey-Bass

Sergrovanni, T. J. (2001). The principalship: A reflective practice perspective (4th edition). New York: Allyn and Bacon.

Somech, A. \& Wenderow, M. (2006). The impact of participative and directive leadership on teachers' performance: The intervening effects of job structuring, decision domain, and leader-member exchange. Educational Administration Quarterly 2006; 42; 746- 
772.

UNESCO. (1990). World declaration on education for all and framework for action to meet basic needs. International Consultative Forum on Education on Education for All. Paris: UNESCO.

UNESCO. (1994). The Salamanca world conference on special needs education: Access and quality. Spain: UNESCO \& The Ministry of Education Spain.

UNESCO. (2005). Millenium development goals. In guidelines for inclusion: Ensuring access to education for all. Paris: UNESCO.

UNICEF. (2003). The Millenium Development Goals. New York: The United Nations Children's Fund.

Vroom, W. (1964). Work and motivation. New York: John Wiley \& Sons.

Vroom, V. H., \& Jago, A. G. (1998). Situation effects and levels of analysis in the study of leader participation. In F. Dansereau \& F. J. Yammarino (Eds.), Leadership: The multiple-level approaches (pp. 145-159). London: JAI.

Weick, K. E. (1983). Educational organizations as loosely coupled systems. In J. Victor Baldridge \& Terrence Deal (eds.). The dynamics of organizational change in education (pp. 15-37). California: McCutchan. 
